\title{
Role of dynamic MRI in occult cervical canal stenosis
}

\author{
Raghavendra Nayak, Ajay Hegde, Sashanka Kode, Girish Menon
}

Department of Neurosurgery, Kasturba Medical College, Manipal, Karnataka, India

\section{Correspondence to} Dr Ajay Hegde,

dr.ajayhegde@gmail.com

Accepted 2 May 2018

\section{DESCRIPTION}

A 61-year-old elderly man presented to us with complaints of neck pain radiating to bilateral upper limbs with associated tingling and numbness of all four limbs since 8 months. He also had difficulty in walking and performing fine motor activities with his hands. On examination, he had spasticity of all four limbs, with exaggerated reflexes and power of $4 / 5$ in his limbs. On evaluation with a static MRI of the cervical spine, a T2 cord signal hyperintensity was found at the C3-4 junction with no compression noted in sagittal and axial MRI sections. A dynamic $\mathrm{X}$-ray of the cervical spine showed grade 1 listhesis of C3-4 (figure 1). Dynamic MRI of the spine was done with flexion and extension, which clearly demonstrated canal stenosis at the C3-4 junction with both anterior compression and posterior buckling of the ligamentum flavum (LF) on extension and significant reduction of the same on the flexion (figure 2). This additional sequence provided a roadmap for surgical intervention and the patient underwent a C3-4 anterior cervical discectomy and fusion procedure in view of C3-4 G1 listhesis and secondary buckling of the LF.

Dynamic MRI has been increasingly used to demonstrate spinal cord compression, although it has not been a common approach yet. It forms an important investigation in elderly patients with definite long track signs with no clear surgical roadmap. Anteroposterior diameter of the spinal cord increases in flexion and decreases in extension, and this phenomenon gets accentuated in cases of cervical spondylosis. ${ }^{1}$ The dynamic change of LF in extension may be due to thickening of the LF related to inflammatory changes, facet hypertrophy or due to intervertebral disk-height loss. ${ }^{2}$ Dynamic cervical MRI gives us more

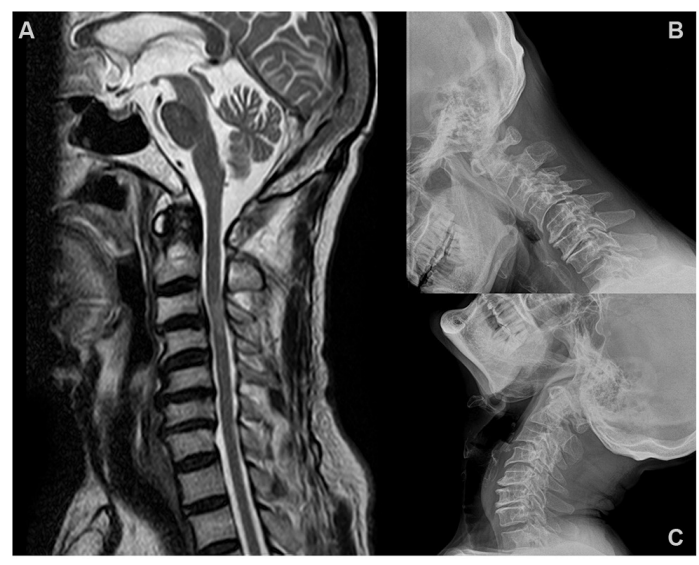

Figure 1 (A) Static MRI-sagittal T2 image showing no significant compression. Cord signal changes noted at C3-4 junction. (B and C) Flexion and extension X-ray films with C3-4 listhesis.

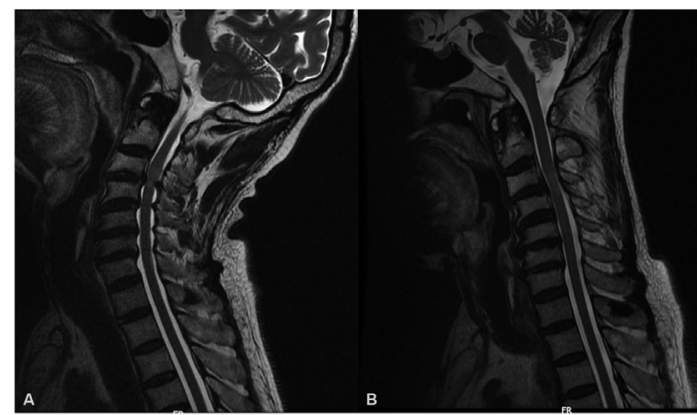

Figure 2 Dynamic MRI. (A) Extension with compression at C3-4 junction with ligamentum flavum hypertrophy.

(B) Reduction of compression in flexion.

significant findings in comparison with a static MRI with $18 \%$ higher chances of diagnosing a posterior cervical compression. ${ }^{3}$ Kim et al concluded that the evaluation of cervical spondylotic myelopathy was improved in $72 \%$ of patients with extension MRI in comparison with neutral MRI. ${ }^{1}$

Thus, dynamic cervical spine MRI should be an important investigation before we decide to write off surgical treatment in patients with cervical myelopathy and cord signal changes without definitive compression on static MRI.

\section{Learning points}

- Signal changes in cervical spinal cord on MRI without definite compression should be evaluated with dynamic MRI series.

- Elderly population with cervical myelopathy with no clear roadmap of surgical procedure should undergo dynamic MRI to offer the best surgical procedure.

- Dynamic MRI is a must before a surgeon writes off surgical intervention in such patients.

Contributors RN: diagnosis, editing, operating surgeon. $\mathrm{AH}$ : write-up. SK: image editing. GM: operating surgeon.

Funding The authors have not declared a specific grant for this research from any funding agency in the public, commercial or not-for-profit sectors.

Competing interests None declared.

Patient consent Obtained.

Provenance and peer review Not commissioned; externally peer reviewed.

(c) BMJ Publishing Group Ltd (unless otherwise stated in the text of the article) 2018. All rights reserved. No commercial use is permitted unless otherwise expressly granted.

\section{REFERENCES}

1 Kim CH, Chung CK, Kim KJ, et al. Cervical extension magnetic resonance imaging in evaluating cervical spondylotic myelopathy. Acta Neurochir 2014;156:259-66. 
2 Chokshi FH, Quencer RM, Smoker WR. The "thickened" ligamentum flavum: is it buckling or enlargement? AJNR Am J Neuroradiol 2010;31:1813-6.

3 Nigro L, Donnarumma P, Tarantino R, et al. Static and dynamic cervical MRI: two useful exams in cervical myelopathy. J Spine Surg 2017;3:212-6.

Copyright 2018 BMJ Publishing Group. All rights reserved. For permission to reuse any of this content visit

http://group.bmj.com/group/rights-licensing/permissions.

BMJ Case Report Fellows may re-use this article for personal use and teaching without any further permission.

Become a Fellow of BMJ Case Reports today and you can:

- Submit as many cases as you like

- Enjoy fast sympathetic peer review and rapid publication of accepted articles

- Access all the published articles

Re-use any of the published material for personal use and teaching without further permission

For information on Institutional Fellowships contact consortiasales@bmjgroup.com

Visit casereports.bmj.com for more articles like this and to become a Fellow 